\title{
Testing the Validity of Keynesian Military Model of Fiscal Side in Case of Pakistan
}

\author{
Ahmed Gulzar ${ }^{a}$, Allah Ditta ${ }^{\text {b }}$, Hafeez ur Rehman ${ }^{\text {c }}$, Naghmana Ghafoor ${ }^{d}$ \\ ${ }^{a}$ PhD scholar in Economics, Department of Economics, University of Management and Technology, Lahore, \\ Pakistan, Email: ahmedgulzar2011@gmail.com \\ ${ }^{\mathrm{b}}$ Assistant Professor of economics, Govt. College Township, Lahore, Higher Education Department, Govt. of the \\ Punjab, Pakistan Email: ad.tahir77@gmail.com \\ ${ }^{c}$ Chairman Department of Economics , University of Management and Technology, Lahore, Pakistan, \\ Email: drhrehmankhan@gmail.com \\ ${ }^{\mathrm{d}}$ Lecturer, Department of Economics, Lahore College for Women University, Lahore, Pakistan \\ Email: naghmana.ghafoor@lcwu.edu.pk
}

\begin{tabular}{|c|c|}
\hline ART & \multirow{10}{*}{$\begin{array}{l}\text { ABSTRACT } \\
\text { The objective of the study was to determine the impact of national } \\
\text { series data from } 1981 \text { to } 2018 \text { on annual frequency on GDP growth rate, } \\
\text { military expenditures as percentage of GDP, imports as percentage of } \\
\text { GDP, unemployment rate, FDI as percentage of GDP and percentage of } \\
\text { population living in agglomeration cities taken from online World } \\
\text { Development Indicators. Johansen Co-integration and VECM } \\
\text { methodology are applied to check the long run relationship and to get } \\
\text { the long run and short run coefficient values. The major findings of this } \\
\text { study explain that there is found the positive and significant relationship } \\
\text { between military expenditures and economic growth of Pakistan both in } \\
\text { long run and in short run. It explains that military expenditures are the } \\
\text { key driver of economic growth both in short run and in the long run. The } \\
\text { impact of imports on GDP growth was also found to be positive and } \\
\text { significant both in long run and in short run. The impact of FDI is found } \\
\text { positive and significant both in the long run and in the short run. The } \\
\text { impact of migration of population to agglomeration cities have huge } \\
\text { impact on growth were observed. The impact of unemployment was } \\
\text { found to be negative on economic growth in short run. }\end{array}$} \\
\hline & \\
\hline 2020 & \\
\hline $\begin{array}{l}\text { Available Online } 30 \text { September } \\
2020\end{array}$ & \\
\hline Кеу & \\
\hline Military Expendi & \\
\hline $\begin{array}{l}\text { Unemployment, FDI, Populat } \\
\text { Pakistan's Economy }\end{array}$ & \\
\hline JEL & \\
\hline E24, & \\
\hline DOI: $10.47067 /$ reads.v6i3.2 & \\
\hline
\end{tabular}

(C) 2020 The authors. Published by SPCRD Global Publishing. This is an open access article under the Creative Commons Attribution-

NonCommercial 4.0

Corresponding author's email address: ahmedgulzar2011@gmail.com

\section{Introduction}

There has been an extensive debate on the nature of relationship between national security and socio-economic development among policy makers, academicians and practitioners with special reference to developing countries. They are of the view that strategic security concerns and socioeconomic developments are two separate domains and must be treated accordingly and more weightage 


\section{Review of Economics and Development Studies, Vol. 6 (3) 2020, 675-686}

should be given to socio-economic development in the public policy framework and action plans. In an article "Prospects of South Asian Cooperation in the Transformed World Post-11 September", J. N. Dixit strongly asserts the separation of strategic-security concerns and socio-economic developmental needs in South Asia1.

Defence expenditures are widely debated as undesirable on any economy. This argument is built on the hypothesis that defence expenditures divert the resources of an economy from development projects. The other argument is that defence expenditures cater to the territorial sovereignty of the state, thereby providing a secure and enabling environment to the citizens to pursue their means of livelihood. This way, it contributes towards socio-economic prosperity in the country. According to SIPRI, world defence expenditures reached \$ 1.63 trillion in 2010 which was 50 percent increase since 2001.

Under this argument, defence expenditure is considered as the most important component of government expenditures which is used to correct short-run socio-economic fluctuations explained by Military Keynesianism. It is taken as the responsibility of the state to pursue the objective of national security and socio-economic development.

Pakistan falls under the category of low income countries with a ranking of $156^{\text {th }}$ in world per capita (according to purchasing power parity, PPP methodology2) adjusted gross national income (GNI) of $\$ 2$, 6oo, while peace ranking is 145 and it is $35^{\text {th }}$ in national security spending ranking.

National security expenditures of Pakistan stand relatively high as it stands at $4.5 \%$ of GDP3 on average from 1995 to 2010 . The reasons for such high defence and national security budget allocations include chronic issues with India, internal security challenges and geopolitical position in the Afghan war. There are socio-economic impacts of these national security expenditures which explain the relationship between national defence expenditure and socio-economic dynamics of growth and development. However, there is declining trend in national security expenditures as percentage of GDP from 1995 (i.e. $6.4 \%$ of GDP) to date (i.e. less than $3 \%$ of GDP).

\subsection{An Analysis of Pakistan's National Security Expenditures}

National security expenditures were on an increasing trajectory till 1999 (on average 6.62 percent of GDP). Afterwards, a declining trend was observed till 2001 and again rose till 2003 and then gave a declining trend. The reasons for these trends include the induction of defence pension in civil budget and foreign military aid after war on terror. The justification of these high national security spendings has been made by the policy makers on the basis of potential and active internal and external threats to national security of Pakistan.

Immediately after Pakistan came into existence, it faced multi-farious problems ranging from influx of refugees, boundary disputes, lack of financial resource to division of assets. These problems exacerbated rivalry cum enmity between Pakistan and India which still continues due to unresolved issues between the two states. These issues include Kashmir dispute, water issue and cross-border terrorism etc. For example, in 1980s, General Zia-ul-Haq the then President of Pakistan refused to even consider any cut in national security expenditures and observed that no one could fight against jets and

\footnotetext{
$1 \mathrm{~J} N$ Dixit is of the view that the defence expenditures in the name of national security are a burden on national exchequer. These expenditures curtail socio-economic development by leaving less resources for other sectors

2 Purchasing Power Parity, (PPP) Methodology basically explains the rate at which equal basket of goods may be purchased in two different countries with same value of respective countries' currency.

3 Here Gross Domestic Product (GDP) is taken in constant terms. It does not include any effect of inflation in its value.
} 


\section{Review of Economics and Development Studies, Vol. 6 (3) 2020, 675-686}

nuclear submarines with sticks and so Pakistan had to match its arsenal capacity with its adversaries. The security concerns on both sides have resulted in an arms race between India and Pakistan. The action-retaliation approach led to an escalation in the race for stockpiling of arsenals which resulted in high budgetary allocation for national security.

The Soviet invasion of Afghanistan in 1979 left grave imprints on Pakistan's security strategy paradigm as the country emerged as a front line state in the proxy war against communism. This placed Pakistan in a two pronged threat scenario such as no other South Asian state has ever experienced. More recently, the war on terror in Afghanistan also placed Pakistan as the number one ally of NATO. Pakistan is also fighting against insurgency in Balochistan. Expenditures on national security are a sine qua non for effectively responding to the internal and external threats being faced by the country.

This study will explore the socio-economic dynamics of national security expenditures in terms of military and non-military threats from within the country and across the borders. The scale of these impacts will also be examined. The impact of these factors will be examined primarily on the patterns of consumption, distribution of wealth and incomes, differential improvements in metrics such as GDP per capita, literacy rates, level of employment generation, life expectancy, health indicators and overall quality of life.

The relationship between national security expenditures and socio-economic factors will be assessed by using the Keynesian Military Model of Fiscal Side. Keynesian Military Model of Fiscal Side explains that the expenditures on national defence in the name of national security may be taken as public good and their contribution towards the socio-economic activity of a society may be reckoned.

\section{Literature Review}

Joerding (1986) analyzed the relationship between military expenditure, external and internal security and economic growth. In this perspective, he basically discussed the fundamental questions: Does economic growth initiate defence spending? Does defence spending initiate economic growth? Or do structural changes in an economy affect defence spending? (Joerding (1986) used partial equilibrium analysis to study the relationship among military expenditures, internal and external threats and economic growth in continuous timeframe). Looney (1989) analyzed the determinants of defence spending. He found national income as one of the most significant factor of military spending.

Tahir et' al (1999) analyzed the relationship between economic growth and defence expenditure for Pakistan and other least developed countries. Granger causality test technique was used on data series of real output and defence expenditure on quarterly frequency from 1961 to 1997. They found a mixed relationship in case of Pakistan, Iran and India. Lai et' al (2002) analyzed the defence expenditures as one of the factors of balanced economic growth by using endogenous growth model. They found that defence expenditures lead to socio-economic growth and development.

Khan (2004) tested the defence (military) Keynesian Hypothesis for Pakistan. He used Johansen's Co-integration technique to find long run causal relationship and VEC model to capture short run effects. He used data from 1951 to 2003 on annual frequency. He found that defence expenditures do not block significantly the economic growth in Pakistan. He also found that Military Keynesian Hypothesis does not hold true. Hou (2009) analyzed the causal relationship between defence expenditure and socio- economic growth in thirty six developing countries by using cross sectional panel data and found that there is negative effect of defence expenditure on economic growth. 
Review of Economics and Development Studies, Vol. 6 (3) 2020, 675-686

Ando 4(2009) divided the economy into two sectors i.e. private and defence and then analyzed the relationship between defence spending and socio-economic dynamics with the sample of 109 countries including 30 OECD countries. He used panel data from 1995 to 2003. He found that growth of defence spending affect positively on socio-economic factors.

It is hypothesized that national security spending and economic growth are positively co-related. National security spending increases with the increasing size of an economy to maintain internal security and to protect itself from external aggression.

\section{Analytical Framework for National Security and Socioeconomic Development (Keynesian Military Model of Fiscal Side)}

After creation of Pakistan, the majority of areas constituting the new state were without adequate public institutions and physical infrastructure. The reason for these inadequacies was the British mistrust towards Muslims during the Colonial Rule and their policy of 'Divide and Rule'. Hence, the Muslim majority areas were deliberately left backward to suppress any form of revolt from the Muslims to regain their past glory. Resultantly, after independence, due to weak infrastructure, all the governments in Pakistan had to consistently strive for coping with the basic issues such as rural poverty, supply of basic needs for the majority of the population including health, education, shelter alongwith issues related to economic development and national security.

It is argued extensively in the literature of 'International Political Economy' that the increase in expenditures on national security contributes towards economic growth and social harmony by providing peaceful and friendly environment for investment and for pursuing other business ventures. However some political economists have a divergent view from the aforesaid argument and claim that the opportunity cost of diversion of national resources into expenditures of national security agenda is so high that it hinders the socio-economic growth from potential level.

To substantiate the former argument, it is observed that the growth rates in the eras of Gen Zia ul Haq and Gen Pervez Musharraf have been impressive as compared to other regimes during the last four decades, although the expenditures on national security were high in these periods. This reflects a positive relationship between peace and economic activity. One School of Thought propounds that an increase in national security expenditures negatively affects job opportunities in other sectors because less financial resources are left for investment purposes in these sectors. This trend negatively impacts the socio-economic fabric of the society. However, this argument does not hold true especially in the case of developing countries where endemic law \& order and security situation like Sri-Lanka, Pakistan and Afghanistan. In case of Pakistan, since the last many decades, the internal and external threats to national security have been manifold. Terrorist attacks including suicide bombings at public places and government premises have substantially increased. These incidents have disrupted socioeconomic activities across the country in all the major sectors of the economy including the industrial sector, agriculture sector, tourism and other areas of economic investment.

In view of the prevailing security situation, the government has to focus on strengthening the capacities and capabilities of the Law Enforcement Agencies and the Defence institutions to fight the menace of terrorism in all its forms and manifestations. This investment in national security apparatus is critical for establishing the Writ of Law in the country and for creating a peaceful and enabling

4 Ando (2009) divided the economy into two sectors in terms of allocation of resources i.e. private and defence rather than private and public. In his analysis he treats all the government resources as to provide the business environment to the private sector. In this regard, he considers defence expenditures as public good. 


\section{Review of Economics and Development Studies, Vol. 6 (3) 2020, 675-686}

environment for the economic development and prosperity of its citizens.

The literature available on 'Economics of National Security'5 reveals an inconsistency in explaining the strong relationship between national defence and socio-economic development. This has been true with respect to cross country analysis as well as an individual country. Prevalent ambiguity relating to the subject matter is highlighted by Chan, who contends that the overall studies in the literature have ignored the theoretical basis and focused on empirical aspects only of the relationship between national defence and economic growth. Thus national security as a service has not been considered as a public good but rather as an expenditure item. Therefore, it is treated as a burden instead of being recognized as a contribution to the socio-economic development of a state.

In the domain of Government sector production both services and goods are the part and parcel of the national production. The worth of the government production is very difficult to be estimated because of the clear issues of externalities and indirect benefits of public goods. Under such conditions, the value of public goods is estimated on the basis of the hypothesis that expenditure is equal to the value. According to this type of definition, the worth of national security service as a public good is equal to its expenditures. Thus in analyzing national security and socio-economic development, national security must be evaluated as an intermediate good and must be treated as a major contributor to the national economy.

Keeping in view the perspective propounded above, an analytical framework has been developed to understand the types of contributions made by national security considerations in the socio-economic domain. In this framework, national security is assumed as a public good. National security encompasses a broad gamut of areas including protection of lives and property of citizens from internal and external threats.

Within this framework, the role of national security in socio-economic development can be seen with special reference to input-output analysis (Input-output analysis in standard practice is used to determine and quantify the scale of effects of inputs on output) while adding up all the externalities 6 of national security which can happen in the short run as well as in the long run. The current literature has only treated the indirect benefits of national security and has made up the models to test the nature of relationship between national security expenditures and socio-economic growth. The main cause of not considering the direct benefits of national security is that there is difficulty of separating the direct benefits such as the additional production for the additional increase in effective national security. The assumptions of the model are as under;

- The direct benefits of national security and its positive externalities are taken with reference to all stakeholders.

- Employment is considered as a basic indicator of social development while the income (GDP) is considered as a basic indicator of economic activity.

- There is direct relationship between employment and income.

- Employment and income are taken as basic indicators of socio-economic development. The country has not reached its potential employment level.

5 In the subject, 'Economics of National Security', the financial, economic and cost-benefit analyses are made from different aspects of national security expenditures and their contribution towards socio-economic activity within a limited time frame given a set of pre-conditions.

6 Externalities are defined as the effects of one's actions on others. Externalities can both be positive and negative. For example, smoking has negative externalities. 


\section{Review of Economics and Development Studies, Vol. 6 (3) 2020, 675-686}

- The national security of a given country operates efficiently and effectively, there are no hindrances for the national security to operate.

- National Security takes the minimum value that goes to gross national product rather it expresses the government expenditures.

Both macro and micro analyses will be made in the final construct of the empirical model. Micro analysis entails the externality effects of an improvement in the national security situation at individual level, whereas, macro analysis explains the effects of an improvement in the national security situation on employment and income at national level.

In the empirical model, national security expenditures which are equal to the amount of expenses incurred on armed forces, military equipment, and other national security agencies of the country are taken as inputs. The National Security Stratagem includes military forces, paramilitary forces, police and other mechanisms of national security etc. Under national security, the paramilitary forces, police and the private security mechanisms are not usually taken into consideration. However, in this model, the national security includes Ministry of Defence, paramilitary forces, armed forces, Pakistan Police and other security agencies. The reason to include these forces in the National Security Stratagem is that the paramilitary forces and police are playing crucial role in the counter terrorism strategies to save the social fabric of the society.

National Security expenditures are taken as input and the deterrence which is the result of national security expenditures and its impact on employment, income, social transformation and economic development is taken as output. The stoppage of the violence that has linkages with development as indirect effects under input-output relationship will be examined and secondly, the linkage between national security and economic growth and development will be re-assessed. To wrap up the debate, the Keynesian Military Model of Fiscal Side explaining the role of national security in the development of a country is shown below in the form of input-output transmission mechanism. Here, national security expenditures are supposed to be used in way to establish internal as well as external security. At the second stage, the internal and external security provides a peaceful, stable and investment friendly environment. At third stage, the investors' confidence is restored and they start economic activities which generate employment and induce high economic growth. At fourth stage, high employment generation and economic growth leads towards inclusive growth, self esteem, social transformation and economic development. 

Side)

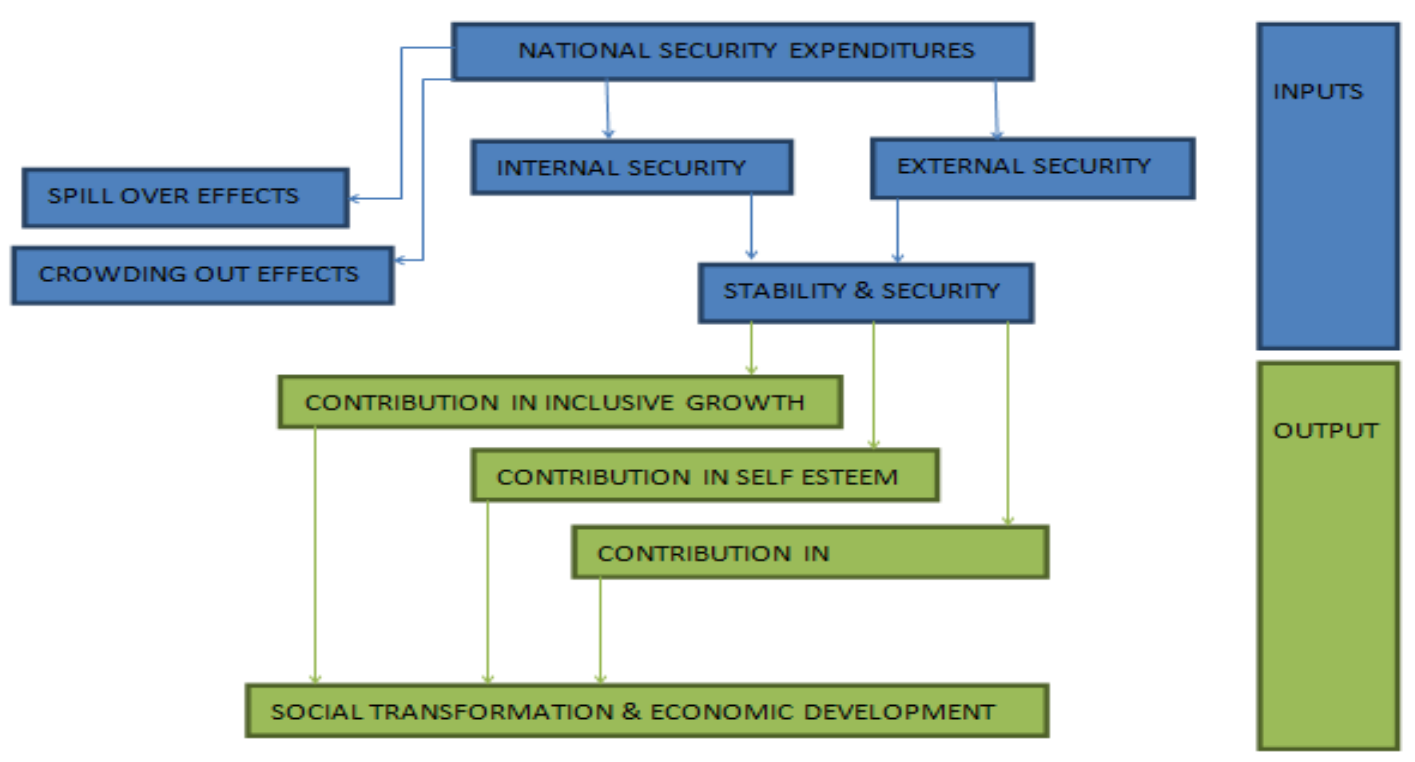

\section{Methodology and Data Sources}

The relationship between national security expenditures and socio-economic factors are assessed by using the Keynesian Military Model of Fiscal Side. This model explains the spillover effects of national security expenditures on socio-economic development in the context of Pakistan. Time series data from 1981 to 2018 on annual frequency on GDP growth rate, military expenditures as percentage of GDP, imports as percentage of GDP, unemployment rate, FDI as percentage of GDP and percentage of population living in agglomeration cities taken from online WDI7,. Johansen Co-integration and VECM methodology are applied to check the long run relationship and to get the long run and short run coefficient values. The data is taken on annual frequency where one point of data is considered as average over one year. The simplistic functional form of the Keynesian Military Model of Fiscal Side is as under:

$$
\text { GDP = } f \text { (imports,FDI, Military expenditures, population, unemployment) }
$$

Log-linear Models were used to get more reliable and robust results for achieving the objective of the study.

$$
\begin{gathered}
\operatorname{lnGDP}=\beta_{0}+\beta_{1} \ln \mathrm{ME}+\beta_{2} \ln \mathrm{M}+\beta_{3} \ln F D I+\beta_{4} \ln U \mathrm{M}+\beta_{5} \ln \mathrm{PAC}+\varepsilon_{\mathrm{t}} \\
\ln G D P=f(\ln x, \ln m, \ln f d i, \text { lnme, lnpac,lnum })
\end{gathered}
$$

Where, GDP = Growth rate of Gross domestic product, $\mathrm{UM}=\%$ of unemployment, $\mathrm{M}=$ Total imports $\%$ of GDP, FDI = Foreign Direct investment as \% of GDP, ME = military expenditure \% of GDP as proxy of national security expenditures, PAC = population living in agglomeration cities. The growth rate of GDP is calculated on constant prices. It does not include any inflationary impact. It explains the direction of socio-economic development. This indicator also explains the macro-economic stability of a country showing a strong relationship between public policy and economic growth.

7 WDI stands for World Development Indicator. This data set is published by the World Bank. 
Review of Economics and Development Studies, Vol. 6 (3) 2020, 675-686

The data set on defense spending takes the complete range of capital and current spending on military ventures and men like paramilitary forces, ministry of defense, operations, maintenance, procurement and military and security research \& development. It does not include the civil defense spending, conversion or destruction of weapons and expenditures on previous military activities. Defense expenditures share a large portion of total income consumption of an economy therefore, it is argued on the usefulness and wasteful tendencies of such expenditures in terms of socio-economic development by many research scholars. The amount of defence spending entirely depends upon the geo-strategic and regional condition of a country. A country which has more internal and external security threats will spend more on national security and defence and vice-versa.

The data set on imports are taken from WDI. It includes the imports of goods and does not include the transfer payments and factor services. Imports of final goods and services are considered as burden on an economy. However, the imports of goods which help in developing the technology of local industry in terms of making them competitive on international level are considered favorable. The imports in some sectors also help in developing human resources by increasing the professionalism and cognitive skill of local labourforce. The recommendations of the study are made on the basis of empirical estimates and their interpretations

\section{Results and Discussion}

First of all, the descriptive statistics of variables were estimated, which are shown in table 1 below. The p-values of Jarque-Bera explain that the data on all variables are normally distributed. The coefficient of correlation and variance inflation factor (VIF) were calculated and shown in tables 2 and 3 respectively. The values of VIF for all variables are under 10 and hence explain that there is no issue of multicollinearity.

Table 1: Descriptive Statistics

\begin{tabular}{|l|l|l|l|l|l|l|}
\hline & LNGDP & LNFDI & LNM & LNME & LNPAC & LNUM \\
\hline Mean & 1.454073 & -0.330413 & 2.979035 & 1.594156 & 2.865265 & 1.112881 \\
\hline Median & 1.57822 & -0.389944 & 2.98446 & 1.68919 & 2.856953 & 1.406881 \\
\hline Maximum & 2.069488 & 1.299735 & 3.151504 & 1.944717 & 2.999319 & 2.057963 \\
\hline Minimum & 0.014293 & -2.276267 & 2.683295 & 1.183328 & 2.805068 & -0.922057 \\
\hline Std. Dev. & 0.516384 & 0.766673 & 0.136102 & 0.282595 & 0.054746 & 0.881011 \\
\hline Skewness & -1.010368 & -0.022197 & -0.714551 & -0.137517 & 0.716782 & -1.162511 \\
\hline Kurtosis & 3.361135 & 3.489718 & 2.549169 & 1.313244 & 2.559184 & 3.132899 \\
\hline Jarque-Bera & 6.145115 & 0.352618 & 3.274801 & 4.259485 & 3.280407 & 7.909115 \\
\hline Probability & 0.046303 & 0.838359 & 0.194485 & 0.118868 & 0.193941 & 0.019167 \\
\hline Sum & 50.89257 & -11.56445 & 104.2662 & 55.79545 & 100.2843 & 38.95084 \\
\hline Sum Sq. Dev. & 9.066172 & 19.98478 & 0.629808 & 2.715247 & 0.101902 & 26.39016 \\
\hline
\end{tabular}

Table 2: Coefficient of Correlation

\begin{tabular}{|c|c|c|c|c|c|}
\hline & LNFDI & LNM & LNME & LNPAC & LNUM \\
\hline LNFDI & 1 & & & & \\
\hline LNM & -0.170553 & 1 & & & \\
\hline LNME & -0.562047 & 0.490254 & 1 & & \\
\hline LNPAC & 0.484248 & -0.372667 & -0.881652 & 1 & 1 \\
\hline LNUM & -0.442602 & -0.370746 & 0.435402 & -0.357532 & 1 \\
\hline
\end{tabular}


Review of Economics and Development Studies, Vol. 6 (3) 2020, 675-686

Table 3: VIF

\begin{tabular}{|c|c|c|c|c|c|}
\hline & LNFDI & LNM & LNME & LNPAC & LNUM \\
\hline LNFDI & - & & & & \\
\hline LNM & 1.029959806 & - & & & \\
\hline LNME & 1.461767821 & 1.316393949 & - & & \\
\hline LNPAC & 1.306329116 & 1.16127927 & 4.490552421 & - & - \\
\hline LNUM & 1.243621049 & 1.159356571 & 1.233920324 & 1.146564321 & - \\
\hline
\end{tabular}

The times series were tested to check the stationarity through unit root test with the hypothesis $\left(\mathrm{H}_{\mathrm{O}}\right)$ that the time series is stationary in the econometric model. Otherwise, the whole analysis goes in vain and all the results of regression become spurious because a non-stationary time series is not mean reverting and has infinite memory. This study used ADF (Augmented Dickey-Fuller, 1979) test and Phillip Perron test to find out the stationarity of the series. Table 4 below explains that all the variables are I (1) in their levels and I (o) in their first differences at five percent level of significance.

Table 4: Unit Root Test (P-values)

\begin{tabular}{|c|c|c|c|c|c|}
\hline \multirow{2}{*}{ Variables } & \multicolumn{2}{|c|}{$\mathrm{I}(\mathrm{o})$} & \multicolumn{2}{c|}{$\mathrm{I}(1)$} & ADF test \\
\cline { 2 - 5 } & ADF test & PP test & & PP test \\
\hline LNGDP & 0.15 & 0.57 & $\Delta$ LNGDP & 0.00 & 0.00 \\
\hline LNFDI & 0.11 & 0.29 & $\Delta$ LNFDI & 0.00 & 0.00 \\
\hline LNM & 0.23 & 0.11 & $\Delta$ LNM & 0.00 & 0.00 \\
\hline LNME & 0.7 & 0.82 & $\Delta$ LNME & 0.01 & 0.00 \\
\hline LNPAC & 0.99 & 0.99 & $\Delta$ LNPAC & 0.01 & 0.00 \\
\hline LNUM & 0.45 & 0.49 & $\Delta$ LNUM & 0.014 & 0.00 \\
\hline
\end{tabular}

It explains the stationarity by using ADF and concluded that all the variables are stationary at first difference. The Johansen maximum likelihood method is generally used to analyze the long-run relationship among variables when all variables are I(1) at their levels and I(O) at their first difference. If the critical values are less than max eigen values and trace statistics (based on likelihood ratio) then the null hypothesis $\mathrm{H}_{\mathrm{o}}$ is rejected.

Here $\mathrm{R}=\mathrm{O}$ which shows that there is no co-integration is seen at $\mathrm{R}=\mathrm{O}$ because there is no cointegrating vector is found. Now at $R<1$, the critical values are lower than the estimated values which refer to the rejection of null hypothesis that there is co-integrating factor. It explains that even at $\mathrm{R}<1$ there is no long run relationship found among the variables. At $\mathrm{R}<2$, the critical values i.e. the trace values and the Eigen values are greater than the tabulated values which explain that there is two cointegrating vectors. It explains that there is stable long run relationship among the variables, which is shown in the table 5 and 6.

Table 5: Unrestricted Cointegration Rank Test (Trace)

\begin{tabular}{|l|l|l|l|l|}
\hline Hypothesized & & Trace & 0.05 & \\
\cline { 4 - 5 } No. of CE(s) & Eigenvalue & Statistic & Critical Value & Prob. $^{* *}$ \\
\hline None * & 0.947113 & 164.4704 & 95.75366 & 0 \\
\hline At most 1 * & 0.676044 & 76.28247 & 69.81889 & 0.0139 \\
\hline At most 2 & 0.485069 & 42.46804 & 47.85613 & 0.146 \\
\hline $\begin{array}{l}\text { Trace test indicates 2 cointegrating eqn(s) at the } 0.05 \text { level, * denotes rejection of the hypothesis at the } 0.05 \text { level, } \\
* * \text { MacKinnon-Haug-Michelis (1999) p-values }\end{array}$
\end{tabular}


Review of Economics and Development Studies, Vol. 6 (3) 2020, 675-686

Table 6: Unrestricted Cointegration Rank Test (Maximum Eigenvalue)

\begin{tabular}{|l|l|l|l|l|}
\hline $\begin{array}{l}\text { Hypothesized } \\
\text { No. of CE(s) }\end{array}$ & Eigenvalue & $\begin{array}{l}\text { Max-Eigen } \\
\text { Statistic }\end{array}$ & $\begin{array}{l}\text { 0.05 } \\
\text { Critical Value }\end{array}$ & Prob. $^{* *}$ \\
\hline None ${ }^{*}$ & 0.947113 & 88.18789 & 40.07757 & 0 \\
\hline At most 1 & 0.676044 & 33.81443 & 33.87687 & 0.0509 \\
\hline At most 2 & 0.485069 & 19.91164 & 27.58434 & 0.3473 \\
\hline At most 3 & 0.342859 & 12.59569 & 21.13162 & 0.4901 \\
\hline \multicolumn{2}{|l}{ Max-eigenvalue test indicates 1 cointegrating eqn(s) at the 0.05 level } \\
\hline
\end{tabular}

In the next step, VAR lag length criteria were used to determine the optimal lag order of the variables.

Table 6: VAR lag length criteria

\begin{tabular}{|l|l|l|l|l|l|l|}
\hline Lag & LogL & LR & FPE & AIC & SC & HQ \\
\hline O & 29.18086 & NA & $8.59 \mathrm{E}-09$ & -1.545391 & -1.265151 & -1.45574 \\
\hline 1 & 214.0986 & 283.5405 & $4.42 \mathrm{E}-13$ & -11.47324 & -9.511564 & -10.84568 \\
\hline 2 & 304.0157 & $101.9060^{*}$ & $1.66 \mathrm{e}-14^{*}$ & $-15.06771^{*}$ & $-11.42460^{*}$ & $-13.90225^{*}$ \\
\hline
\end{tabular}

At the next step Johansson Cointegration was used to determine long run coefficient values and ECM method was used to determine the short run coefficient values, which are shown in table 7 . There is found the positive and significant relationship between military expenditures and economic growth of Pakistan both in long run and in short run. It explains that military expenditures are the key driver of economic growth both in short run and in the long run. The results show that 1 increase in military expenditures causes increase in growth rate of GDP by 2.43 percent in long run and 0.026 percent in the short run. The impact of imports on GDP growth was also found to be positive and significant both in long run and in short run. 1 percent increase in imports cause increase in GDP growth by 5.7 percent in long run and 0.07 percent in short run. The impact of FDI is found positive and significant both in the long run and in the short run. One percent increase in FDI causes increase in GDP by 0.733 in the long run and 0.2 percent in short run. The impact of migration of population to agglomeration cities have huge impact on growth were observed. One percent increase in PAC causes 26.27 percent increase in GDP growth in the long run while in short run it impact is minimal. The impact of unemployment was found to be negative on economic growth in short run. The values of $\mathrm{ECM}_{\mathrm{t}-1}$ was calculated of about -.39 . This explains that long run equilibrium will be restored in about 2.56 years.

Table 7: Results

\begin{tabular}{|l|l|l|l|l|l|}
\hline \multicolumn{2}{|c|}{ Long run Johansen Cointegration test } & \multicolumn{3}{l|}{ Short run ECM Methodology } \\
\hline Varible & coefficient value & t-statics & Variable & coefficient value & t-statics \\
\hline LNFDI & 0.733 & 8.32 & $\Delta$ LNFDI & 0.2 & 2 \\
\hline LNM & 5.7 & 6.65 & $\Delta$ LNM & 0.07 & 3.34 \\
\hline LNME & 2.43 & 3.72 & $\Delta$ LNME & 0.026 & 1.99 \\
\hline LNPAC & 26.27 & 7.08 & $\Delta$ LNPAC & 0.001 & 4.55 \\
\hline LNUM & 0.84 & 7.66 & $\Delta$ LNUM & -0.003 & -0.025 \\
\hline \multicolumn{7}{|l}{} & ECM(t-1) & -0.39 & -3.68 \\
\hline
\end{tabular}

The diagnostic tests for examining the serial correlation, functional form, normality and heteroscedasticity among the variables are presented in the tables 8, 9, 10 and 11 below. The p-values of all diagnostics are greater than .1, which accepts the null hypotheses that there is no issue of any of the diagnostics in the estimation. 
Review of Economics and Development Studies, Vol. 6 (3) 2020, 675-686

Table 8: VEC Residual Serial Correlation LM Tests

\begin{tabular}{|c|c|c|}
\hline Lags & LM-Stat & Prob \\
\hline 1 & 37.52881 & 0.3989 \\
\hline 2 & 28.35155 & 0.8144 \\
\hline Probs from chi-square with $36 \mathrm{df}$. & \\
\hline
\end{tabular}

Table 9: VEC Residual Heteroskedasticity Tests

\begin{tabular}{|c|c|c|}
\hline Joint test: & \multicolumn{2}{|l|}{} \\
\hline Chi-sq & df & Prob. \\
\hline 288.0143 & 294 & 0.5875 \\
\hline
\end{tabular}

Table 10: VEC Residual Normality Tests

\begin{tabular}{|l|l|l|l|l|}
\hline Component & Skewness & Chi-sq & df & Prob. \\
\hline Joint & & 9.335712 & 6 & 0.1556 \\
\hline
\end{tabular}

\section{Table 11}

Inverse Roots of AR Characteristic Polynomial

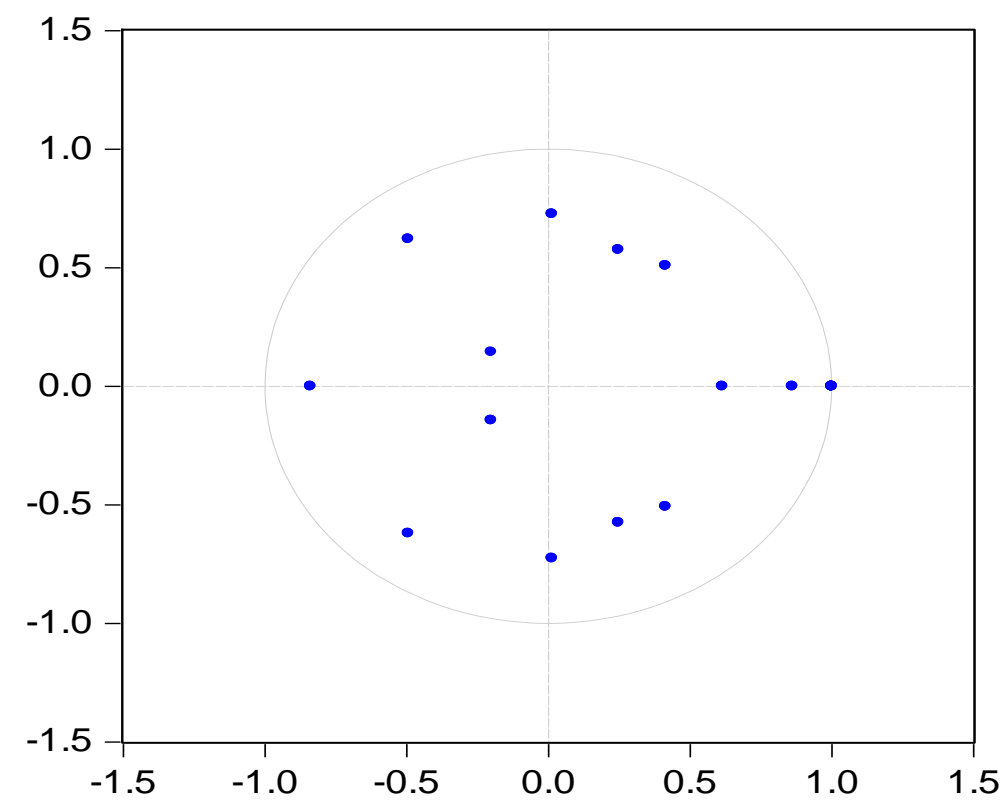

6. Conclusion

The major findings of this study explain that there is found the positive and significant relationship between military expenditures and economic growth of Pakistan both in long run and in short run. It explains that military expenditures are the key driver of economic growth both in short run and in the long run. The results show that 1 increase in military expenditures causes increase in growth rate of GDP by 2.43 percent in long run and 0.026 percent in the short run. The impact of imports on GDP growth was also found to be positive and significant both in long run and in short run. 1 percent increase in imports cause increase in GDP growth by 5.7 percent in long run and 0.07 percent in short run. The impact of FDI is found positive and significant both in the long run and in the short run. One percent increase in FDI causes increase in GDP by 0.733 in the long run and 0.2 percent in short run. The impact of migration of population to agglomeration cities have huge impact on growth were observed. One percent increase in PAC causes 26.27 percent increase in GDP growth in the long run while in short run it impact is minimal. The impact of unemployment was found to be negative on economic growth in short run. The values of $\mathrm{ECM}_{\mathrm{t}-1}$ was calculated of about - .39. This explains that 
long run equilibrium will be restored in about 2.56 years.

National security expenditures have increased due to rise in non-traditional warfare and the emergence of non-state actors. These expenditures are essential to ensure peace and business friendly environment in the country so that the targeted levels of GDP growth are attained. The policy makers should develop a comprehensive national security strategy to address all kinds of issues and challenges to national security like insurgency in Baluchistan, militancy in tribal areas and Khyber Pakhtun khawa, bhatta issue and law and order situation in Karachi. Primarily, the security problem arises from the issues of ethnicity, identity, tribalism and segmentation of the society. The national security strategy must entail these aspects in depth in its phase-wise implementation plans. The comprehensive national security must focus on all dimensions of socio-economic and socio-political life of the society. On political front, it must have such a framework in which all ethnic groups may be entertained in power equation. On economic front, it must have comprehensive plan to address structural issues in the system so that the participation from all segments of the society in the socio-economic development may be made possible. In this way the peace of the country and the security of the life and property of the people of Pakistan may be guaranteed. This is the pre-condition of business friendly environment and socio-economic development.

\section{References}

Ando, Shio (2009), The impact of defense expenditure on economic growth: Panel data analysis based on the Feder Model. The International Journal of Economic Policy Studies, Volume 4(8), pp. 141-154.

Aslam, Rabia (2007), Measuring the peace dividend: Evidence from developing economies. Defence and Peace Economics, Volume 18(1), pp. 39-52.

Batchelor, P., P. Dunne and G. Lam (2002), The demand for military spending in South Africa. Journal of Peace Research, Volume 39(3), pp. 339-354.

Joerding, W. (1986), Economic growth and defense spending: Granger causality. Journal of Development Economics, Volume 21(1), pp. 35-40.

Hou, Na (2009), Arms Race, Military Expenditure and Economic Growth in India. Ph.D. thesis, Department of Economics, The University of Birmingham.

Khan, Mahmood-ul-Hasan (2004), Defense expenditure and macroeconomic stabilization: Causality evidence from Pakistan. SBP Working Paper Series, No. 6.

Lai, Ching-chong, Jhy-yuan Shieh and Wen-Ya Chang (2002), Endogenous growth and defense expenditures: A new explanation of the Benoit Hypothesis. Defence and Peace Economics, Volume 13(3), pp. 179-186.

Looney, Robert (1989), Impact of arms production on income distribution and growth in the Third World. Journal of Economic Development and Cultural Change, Volume 38(1), pp. 145-153.

Tahir, Rizwan and G. M. Sajid (1999), Defence spending and economic growth in less developed countries: Re-examining the issue of causality. Government College Economic Journal, Vol 32(1\&2), pp. 27-39. 